University of Nebraska - Lincoln

DigitalCommons@University of Nebraska - Lincoln

$5-14-2008$

\title{
Evaluation of NASA satellite- and assimilation model-derived long- term daily temperature data over the continental US
}

Jeffrey W. White

U.S. Arid Land Agricultural Research Center, jeffrey.white@ars.usda.gov

Gerrit Hoogenboom

University of Georgia

Paul W. Stackhouse, Jr.

NASA Langley Research Center

James M. Hoell

Science Systems and Applications, Inc.

Follow this and additional works at: https://digitalcommons.unl.edu/nasapub

Part of the Physical Sciences and Mathematics Commons

White, Jeffrey W.; Hoogenboom, Gerrit; Stackhouse, Jr., Paul W.; and Hoell, James M., "Evaluation of NASA satellite- and assimilation model-derived long-term daily temperature data over the continental US" (2008). NASA Publications. 26.

https://digitalcommons.unl.edu/nasapub/26

This Article is brought to you for free and open access by the National Aeronautics and Space Administration at DigitalCommons@University of Nebraska - Lincoln. It has been accepted for inclusion in NASA Publications by an authorized administrator of DigitalCommons@University of Nebraska - Lincoln. 


\title{
Evaluation of NASA satellite- and assimilation model-derived long-term daily temperature data over the continental US
}

\author{
Jeffrey W. White ${ }^{a, *}$, Gerrit Hoogenboom ${ }^{b}$, Paul W. Stackhouse Jr. ${ }^{c}$, James M. Hoell $^{d}$ \\ ${ }^{a}$ U.S. Arid Land Agricultural Research Center, USDA-ARS, 21881 North Cardon Lane, Maricopa, AZ 85239, United States \\ ${ }^{\mathrm{b}}$ University of Georgia, Department of Biological \& Agricultural Engineering, 1109 Experiment Street, Griffin, GA 30223-1797, United States \\ ${ }^{c}$ NASA Langley Research Center, 21 Langley Boulevard, Mail Stop 420, Hampton, VA 23681-2199, United States \\ d Science Systems and Applications, Inc., One Enterprise Parkway, Hampton, VA 23666-5845, United States
}

\section{A R T I C L E I N F O}

Article history:

Received 7 June 2007

Received in revised form

9 May 2008

Accepted 14 May 2008

Keywords:

Phenology

Triticum aestivum

Decision support systems

\begin{abstract}
A B S T R A C T
Agricultural research increasingly is expected to provide precise, quantitative information with an explicit geographic coverage. Limited availability of daily meteorological records often constrains efforts to provide such information through use of simulation models, spatial analysis, and related decision support tools. The Prediction Of Worldwide Energy Resources (NASA/POWER) project at the NASA Langley Research Center provides daily data globally for maximum and minimum temperatures and other weather variables on a $1^{\circ}$ latitude-longitude grid. The data are assembled from a range of products derived from satellite imagery, ground observations, windsondes, modeling and data assimilation. Daily temperature data from NASA/POWER for 1983 to 2004 for the continental US were compared with data of 855 individual ground stations from the National Weather Service Cooperative Observer Program (COOP). Additionally, a wheat (Triticum aestivum L.) simulation model was used to compare predicted time to anthesis using the two data sources. Comparisons of daily maximum temperatures $\left(T_{\max }\right)$ gave an $r^{2}$-value of $0.88(P<0.001)$ and root-meansquared error (RMSE) of $4.1^{\circ} \mathrm{C}$. For minimum temperature $\left(T_{\min }\right)$, the $r^{2}$-value was 0.88 $(P<0.001)$ and RMSE, $3.7^{\circ} \mathrm{C}$. Mean values of $T_{\max }$, and $T_{\min }$ from NASA/POWER were, respectively, $2.4^{\circ} \mathrm{C}$ cooler and $1.1^{\circ} \mathrm{C}$ warmer than the COOP data. Differences in temperature were least during summer months. When data were aggregated over periods of 8 days or more, the RMSE values declined to below $2.7^{\circ} \mathrm{C}$ for $\mathrm{T}_{\max }$ and $\mathrm{T}_{\min }$. Simulations of time to anthesis with the two data sources were also strongly correlated $\left(r^{2}=0.92, P<0.001\right.$, RMSE $=14.5 \mathrm{~d}$ ). Anthesis dates of winter wheat regions showed better agreement than southern, winter-grown spring wheat regions. The differences between the data sources were associated with differences in elevation, which in large part resulted from NASA/ POWER data being based on mean elevations over a $1^{\circ}$ grid cells vs. COOP data corresponding to the elevation of specific stations. Additional sources of variation might include proximity to coastlines and differences in observation time, although these factors were not quantified. Overall, if mountainous and coastal regions are excluded, the NASA/POWER data appeared promising as a source of continuous daily temperature data for the USA for research and management applications concerned with scales appropriate to the $1^{\circ}$ coor-
\end{abstract}

\footnotetext{
* Corresponding author. Tel.: +1 520316 6368; fax: +1530316 6330.

E-mail address: jeffrey.white@ars.usda.gov (J.W. White).

Abbreviations: COOP, NOAA National Weather Service Cooperative Observer Program; NASA/POWER, NASA Prediction Of Worldwide Energy Resources; RMSE, root-mean-squared error; $T_{\max }$, daily maximum temperature; $T_{\min }$, daily minimum temperature; TOB, time of observation bias.

0168-1923/\$ - see front matter. Published by Elsevier B.V.
}

doi:10.1016/j.agrformet.2008.05.017 
dinate grid. It further appeared that the POWER data could be improved by adjusting for elevation (lapse rate) effects, reducing seasonal bias, and refining estimation of actual maximum and minimum temperatures in diurnal cycles.

Published by Elsevier B.V.

\section{Introduction}

Agriculture is increasingly scrutinized at spatial scales larger than the traditional field and farm levels with objectives ranging from monitoring regional water use, to identifying promising zones for production of new crops, to targeting of specific cultivars or traits to specific regions. Spatial assessments often consider climatic variation and increasingly, long-term records of daily weather are required to examine climate risk or trends related to climate change. The analyses, however, are often constrained by the availability and quality of meteorological data. Weather stations may not be available in regions of interest, and individual stations may lack data for long time intervals. Weather data per se may show local variation due to positioning and siting of the station, type of instrument shelter, instrument calibration drift and other factors (Hubbard et al., 2001; Davey and Pielke, 2005; Pielke et al., 2007). Mahmood et al. (2006) concluded that instrument siting can bias average monthly maximum and minimum temperatures by as much as 1.6 and $3.8^{\circ} \mathrm{C}$, respectively. Wu et al. (2005) found that paired weather stations in Nebraska that were situated less than $10 \mathrm{~km}$ apart had root-meansquared errors (RMSE) of $5^{\circ} \mathrm{C}$ for daily values of maximum temperature $\left(T_{\max }\right)$ and $3{ }^{\circ} \mathrm{C}$ for daily minimum temperature $\left(T_{\min }\right)$. In a comparison of nearby ("co-located") automated and manual weather stations, Holder et al. (2006) estimated that automated stations gave values about $0.4^{\circ} \mathrm{C}$ warmer than for $T_{\max }$ and $0.2^{\circ} \mathrm{C}$ cooler for $T_{\min }$. In both studies, time of observation bias (TOB) explained a large portion of the reported differences.

The Prediction Of Worldwide Energy Resources (NASA/ POWER) project at the NASA Langley Research Center provides daily data for maximum and minimum temperatures and other weather variables on a $1^{\circ}$ geographic coordinate grid for the entire globe (Stackhouse, 2006; Table 1). Daily maximum and minimum temperatures are available from 1 January 1983, and data are continuously updated to within 1 month of the current date. The temperature data are obtained from the Goddard Earth Observing System (GEOS) assimilation model, Version 4 (Bloom et al., 2005). Briefly, temperatures from the GEOS-4 model are estimated through an atmospheric analysis performed within a data assimilation context that combines information from irregularly distributed atmospheric observations with a model state obtained from a forecast that is initialized from a previous analysis. The model seeks to assimilate and optimize observational data and model estimates of atmospheric variables. Types of observations used in the GEOS-4 analysis include: (1) land surface observations of surface pressure; (2) ocean surface observations of sea level pressure and winds; (3) sea level winds inferred from backscatter returns from space-borne radars; (4) conventional upper-air data from rawinsondes (e.g., height, temperature, wind and moisture); (5) additional sources of upper-air data include drop sondes, pilot balloons, and aircraft winds; (6) remotely sensed information from satellites (e.g., height and moisture profiles, total precipitable water, and single level cloud motion vector winds obtained from geostationary satellite images).

Emerging from the GEOS-4 analysis are daily global estimates of the vertical distribution of a range of atmospheric parameters. The GEOS-4 estimates are initially on a $1^{\circ}$ latitude $\times 1.25^{\circ}$ longitude global grid at 3-hourly time (GMT) increments. The POWER project extracts the GEOS-4 temperature estimates for $2 \mathrm{~m}$ above the earth's surface,

\section{Table 1 - Daily meteorological variables available on a global $1^{\circ}$ grid through the NASA/POWER project}

\begin{tabular}{|c|c|c|c|}
\hline Variable & Source & Time span & $\begin{array}{l}\text { Availability from } \\
\text { present date }\end{array}$ \\
\hline \multirow{2}{*}{$\begin{array}{l}\text { Daily maximum and minimum } \\
\text { temperatures, daily } \\
\text { average temperature }\end{array}$} & $\begin{array}{l}\text { Goddard Earth Observing System } \\
\text { (GEOS) assimilation model, Version } 4\end{array}$ & January 1983 to December 2006 & $\leq 1$ month \\
\hline & $\begin{array}{l}\text { GEOS, Version } 5.01 \\
\text { GEOS, Version } 5.1\end{array}$ & $\begin{array}{l}\text { January } 2007 \text { to December } 2007 \\
\text { January } 2008 \text { to present }\end{array}$ & \\
\hline Precipitation & $\begin{array}{l}\text { Satellite and ground observations } \\
\text { from the TRMM and GPCP projects } \\
1 \text { January } 1997 \text { to current }\end{array}$ & January 1997 to present & $\leq 2$ months \\
\hline Solar radiation & Satellite observations & $\begin{array}{l}\text { July } 1983 \text { to June 2006; July } \\
2006 \text { to present }\end{array}$ & $\leq 1$ month \\
\hline Dewpoint temperature & $\begin{array}{l}\text { Goddard Earth Observing System } \\
\text { (GEOS) assimilation model, Version } 4 \\
\text { GEOS, Version } 5.01 \\
\text { GEOS, Version } 5.1\end{array}$ & $\begin{array}{l}\text { January } 1983 \text { to December } 2006 \\
\text { January } 2007 \text { to December } 2007 \\
\text { January } 2008 \text { to present }\end{array}$ & $\leq 1$ month \\
\hline
\end{tabular}


(A)

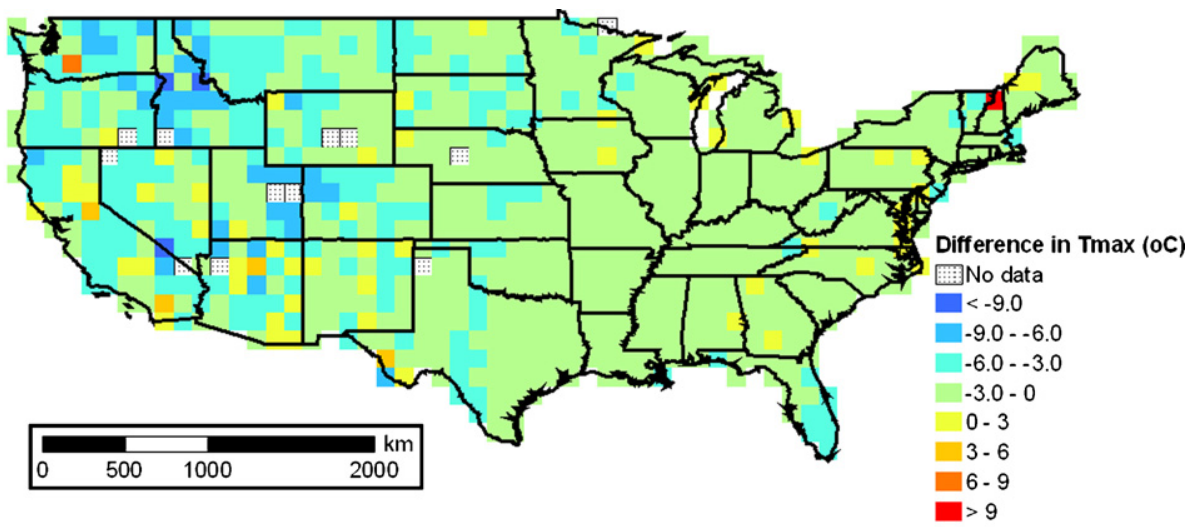

(B)

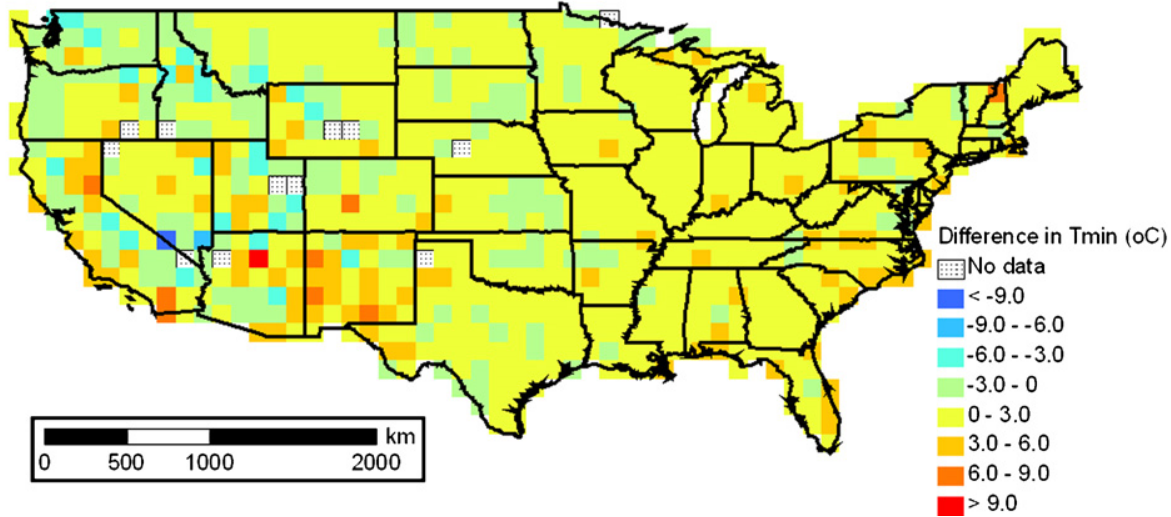

Fig. 1 - Maps of the continental Unites States showing differences in air temperature of NASA/POWER minus COOP data sources for 1983-2004: (A) maximum temperature; (B) minimum temperature.

spatially re-interpolates the temperature values to a global $1^{\circ} \times 1^{\circ}$ grid to be consistent with solar data also provided through POWER, and converts the temporal time steps to local time. The maximum and minimum temperatures for each day are derived from the eight 3-hourly values available for each day, and thus the effective time of observation corresponds to midnight. Download options from the POWER web site (Stackhouse, 2006) include obtaining data in a format compliant with the standards of the International Consortium for Agricultural Systems Applications (ICASA; Hunt et al., 2001, 2006), which facilitates use in software tools such as the Decision Support System for Agrotechnology Transfer (DSSAT; Hoogenboom et al., 2004).

Originally developed for uses related to solar energy, energy consumption, and energy conservation, the NASA/ POWER data appear useful for agricultural and natural ecosystem research. A serious concern, however, is whether the coarse spatial resolution limits their utility: $1^{\circ}$ of longitude is roughly equivalent to $110 \mathrm{~km}$ at the equator and $80 \mathrm{~km}$ at $45^{\circ}$ latitude. Daly (2006) emphasized that terrain and water bodies can affect climate at scales less than $100 \mathrm{~km}$. Besides spatial resolution, there remains the question of whether the temperatures derived from the GEOS- 4 assimilation model exhibit important biases or errors in the data.

The goal of this study was to examine the accuracy of the NASA/POWER temperature data over the continental US by comparing those data with values from stations of the NOAA National Weather Service Cooperative Observers Program
(COOP; NOAA, 2006). However, a direct comparison of temperatures may not capture effects of cumulative or interacting errors, and the impact of errors may be difficult to relate to field-level performance. One feature of ecophysiological models for crop species is that they integrate temperature effects over the crop growth cycle through the prediction of various phenological stages. Therefore, the second objective of this study was to compare simulations of wheat phenology using the two sets of daily temperature data as input for the model. The expectation was that such a test application would help potential users of the NASA/ POWER data understand better the ramifications of possible inaccuracies in those data.

\section{Materials and methods}

Daily data for $T_{\max }$ and $T_{\min }$ were downloaded via the Internet from the NASA/POWER web site (Stackhouse, 2006). The dataset covered the continental US on a $1^{\circ}$ latitude and longitude grid (Fig. 1), representing 867 grid cells. The time interval considered was from 1 January 1983 to 31 December 2004, although the temperature data are available to within 1 month of the present date (see Table 1). Data were provided in a crop model-ready format, so no further processing was required.

Observed temperature data from COOP stations, used as the basis of comparisons, were obtained from NOAA (2006). 
Stations were initially filtered for completeness, resulting in an initial list of approximately 2500 stations. Station locations were mapped, and for each set of stations falling within a single grid cell, the stations were ranked by proximity to the center of the cell. Daily weather data from the station closest to the center were downloaded, checked for errors (including where apparently missing data were assigned values of 0 ), and formatted for analysis. If a station had too many missing data or errors, the next nearest station was used. Stations were rejected if they provided less than 10 years of continuous data between 1983 and 2004, in order to match the period represented in the NASA/ POWER dataset. Missing values for maximum and minimum temperatures were replaced with means of adjacent days if single dates lacked data. If more than $10 \%$ of the data were missing for $T_{\max }, T_{\min }$ or precipitation, the dataset was rejected and another station selected within the grid cell, if available. In total, usable data from 855 stations were obtained. No adjustments were made for time of observation or siting of COOP stations since it was assumed that most end-users would use data as provided from the NOAA web site.

Wheat phenology was simulated using the CSM-CropsimCERES-Wheat model, Version 4.0.2.0 (Jones et al., 2003; Hoogenboom et al., 2004), which contains features of Cropsim (Hunt and Pararajasingham, 1995) and CERES-Wheat (Ritchie, 1991; Ritchie et al., 1998). Vernalization and photoperiod effects on development are specified in species, ecotype and cultivar parameter files. The only developmental stage considered in this study was anthesis, which corresponds to when $50 \%$ of plants have at least one spike with an exserted anther. Rates of development in wheat vary with temperature, including a vernalization requirement, and with photoperiod. The model calculates average daily temperature from $T_{\max }$ and $T_{\min }$. Developmental rates increase linearly with temperatures above a $0{ }^{\circ} \mathrm{C}$ base temperature to an optimum of $26^{\circ} \mathrm{C}$, above which the rate remains maximal. In the absence of vernalization or photoperiod effects, occurrence of stages is determined by integrating rates over growing degree-days (thermal time, with units of ${ }^{\circ} \mathrm{C}$ ). . A stage is reached when development, quantified as accumulation of growing degree-days, reaches a specified limit, which represents the duration of the developmental phase. This requirement is a model parameter and varies with the cultivar and developmental stage in question. Vernalization requirement and photoperiod sensitivity are also assumed to vary with cultivar. Coefficients corresponding to the winter wheat cultivar Bezostaya 1 and the spring wheat Lerma Rojo 64 were used as listed in White et al. (2008).

In order to simulate phenology across the US, a map of wheat planting dates was created based mainly on Hessian
Fly-free dates for winter wheat regions. In assumed wintersown spring wheat regions (Florida to southern Texas, southern Arizona, and California), planting dates were estimated by consulting extension bulletins and reported dates for regional trials. Since the analyses were comparative, moderate errors in planting dates were not a concern.

Basic comparisons of NASA/POWER and COOP temperature data and of simulations using the two datasets were based on ordinary least square regressions using the Generalized Linear Model procedure of the SAS program (SAS Institute, 2000). Independent variables were introduced sequentially as in White et al. (2007). Daily weather data for the continental US show large, predictable annual variations, and thus, obtaining meaningful comparisons required assessing the magnitude of this variation. To represent the annual cycle, sine and cosine signals with a period of 1 year (365.25 days) were included in the regression model. A more complete treatment might use climate normals to de-trend the daily observations but would substantially increase the complexity of the analyses and interpretation.

\section{Results}

\subsection{Initial assessment of COOP data for completeness and accuracy}

Although not an intended objective of this study, processing of the COOP data revealed an unexpectedly high portion of missing data (Table 2). The initial set of 2500 stations had been filtered for completeness, but even the intended nearly final set of 959 stations revealed that approximately $3 \%$ of stations had $10 \%$ or more missing data for 1983-2004 in the subsequent inventory and error analysis. One source of missing data was failure to report values for weekends and holidays. Temperature data had more missing values than precipitation data.

Sporadic cases also occurred where $T_{\max }$ was less than $T_{\min }$. Apparent causes included failure to transcribe negative signs and dropping or inversion of digits. Since COOP data are recorded manually, such errors are probably unavoidable. Unfortunately, comparison of $\mathrm{T}_{\max }$ and $\mathrm{T}_{\min }$ would only detect a small portion of possible errors related to recording and transcribing data.

\subsection{Comparisons of temperature data}

Overall agreement between the NASA/POWER and COOP data for $T_{\max }, T_{\min }$ and $T_{\text {avg }}$ appeared good but evidenced large

Table 2 - Frequencies of missing daily weather data in a sample of 959 COOP stations for the period 1983-2004

Number of stations with a given percentage $(x)$ of missing data

\begin{tabular}{|c|c|c|c|c|c|c|}
\hline \multirow[b]{2}{*}{ Variable } & & & & & & \\
\hline & $x<1 \%$ & $1 \% \leq x<2 \%$ & $2 \% \leq x<5 \%$ & $5 \% \leq x<10 \%$ & $10 \% \leq x<20 \%$ & $20 \% \leq x$ \\
\hline Maximum temperatures & 702 & 104 & 85 & 39 & 21 & 8 \\
\hline Minimum temperatures & 668 & 110 & 103 & 50 & 17 & 11 \\
\hline Precipitation & 673 & 134 & 110 & 34 & 6 & 2 \\
\hline
\end{tabular}

This set of stations is larger than the final set of 855 because it included stations eliminated due to high numbers of missing values, insufficient number of years represented, or falling within cells where another station was closer to the center of the cell. 

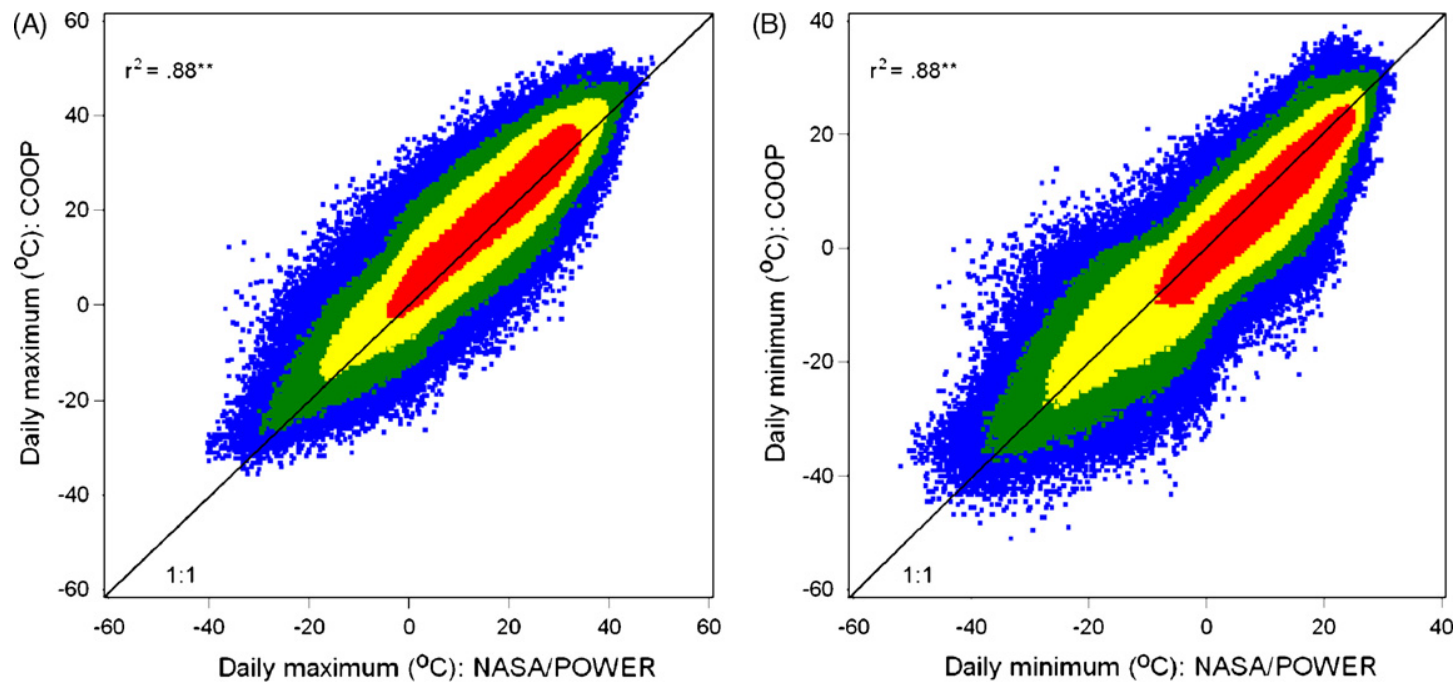

Range: $\| 1-10=11-100$

$101-1000=>1000$

Fig. 2 - Comparison of daily temperature data from the NASA/POWER grid and 857 NOAA COOP weather stations from 1983 to 2005 for the continental US: (A) daily maximum temperature; (B) daily minimum temperature. The range indicates the number of data pairs.

discrepancies for single pairs of daily values (Figs. 1 and 2 and Table 3). The overall mean value of $T_{\max }$ for the NASA/POWER data was $2.4^{\circ} \mathrm{C}$ cooler than the COOP data, values for $T_{\text {min }}$ averaged $1.1^{\circ} \mathrm{C}$ warmer, and values for $\mathrm{T}_{\text {avg }}$ averaged $0.7^{\circ} \mathrm{C}$ cooler. Note in Fig. $1 \mathrm{~A}$ and $\mathrm{B}$ that the largest discrepancies tended to occur in the mountainous regions and along costal areas. This pattern is consistent with the expectation that the NASA/POWER data are representative of the mean value over entire cells. Thus, in mountainous regions, the elevation of a given COOP or other station can differ substantially from the average elevation of the NASA/POWER $1^{\circ}$ grid cell.

Comparisons of elevations reported for grid cells of the NASA/POWER data, which represented mean values over each cell, and of COOP stations indicated that elevations differed by much as $1580 \mathrm{~m}$ (Table 3 and Fig. 3A) with the mean elevation of the NASA/POWER data exceeding the mean COOP elevation by $90 \mathrm{~m}$. The two cells with NASA/POWER values of $T_{\max }$ in April that were over $6^{\circ} \mathrm{C}$ warmer than the COOP stations corresponded to COOP weather stations located on Mt. Rainier, WA and Mt. Washington, NH. The two NASA/POWER grid cells were, respectively, $960 \mathrm{~m}$ lower than the Mt. Rainier station and $1580 \mathrm{~m}$ lower than the Mt. Washington station. The atmospheric lapse rate is approximately $6{ }^{\circ} \mathrm{C} \mathrm{km}^{-1}$ (Hutchinson, 1991; Harlow et al., 2004), so the expectation was that discrepancies in temperature data would largely relate to differences between the elevations of the grid cells of the NASA/POWER data and of the COOP stations. Comparisons of differences in mean temperature with differences in elevation confirmed that the elevation differences explained an additional $1.3 \%$ of the total variation in $\mathrm{T}_{\max }$ and $1.0 \%$ in $\mathrm{T}_{\min }$

Table 3 - Mean, minimum and maximum values of NASA/POWER and COOP daily temperature data for 855 locations on a $1^{\circ}$ latitude and longitude grid covering the continental US and representing a time series from 1983 through 2004

\begin{tabular}{|c|c|c|c|c|}
\hline Variable & Data source & Mean & Minimum & Maximum \\
\hline \multirow[t]{3}{*}{$\mathrm{T}_{\max }\left({ }^{\circ} \mathrm{C}\right)$} & NASA/POWER & 16.2 & -40.3 & 48.7 \\
\hline & COOP & 18.6 & -35.6 & 53.9 \\
\hline & Difference between NASA/POWER and COOP & -2.4 & -48.1 & 33.7 \\
\hline \multirow[t]{3}{*}{$\mathrm{T}_{\min }\left({ }^{\circ} \mathrm{C}\right)$} & NASA/POWER & 6.0 & -51.9 & 32.0 \\
\hline & COOP & 5.0 & -51.1 & 38.9 \\
\hline & Difference between NASA/POWER and COOP & 1.1 & -42.7 & 38.0 \\
\hline \multirow[t]{3}{*}{$\mathrm{T}_{\text {avg }}\left({ }^{\circ} \mathrm{C}\right)$} & NASA/POWER & 11.1 & -46.1 & 39.7 \\
\hline & COOP & 11.8 & -40.0 & 45.7 \\
\hline & Difference between NASA/POWER and COOP & -0.7 & -44.9 & 31.0 \\
\hline \multirow[t]{3}{*}{ Elevation (m) } & NASA/POWER & 740 & 0 & 2680 \\
\hline & $\mathrm{COOP}$ & 650 & -60 & 2810 \\
\hline & Difference between NASA/POWER and COOP & 90 & -1580 & 1270 \\
\hline
\end{tabular}

Elevations correspond to mean values of grid cells for the NASA/POWER dataset and to reported values for COOP stations. Their values are rounded to the nearest $10 \mathrm{~m}$. 

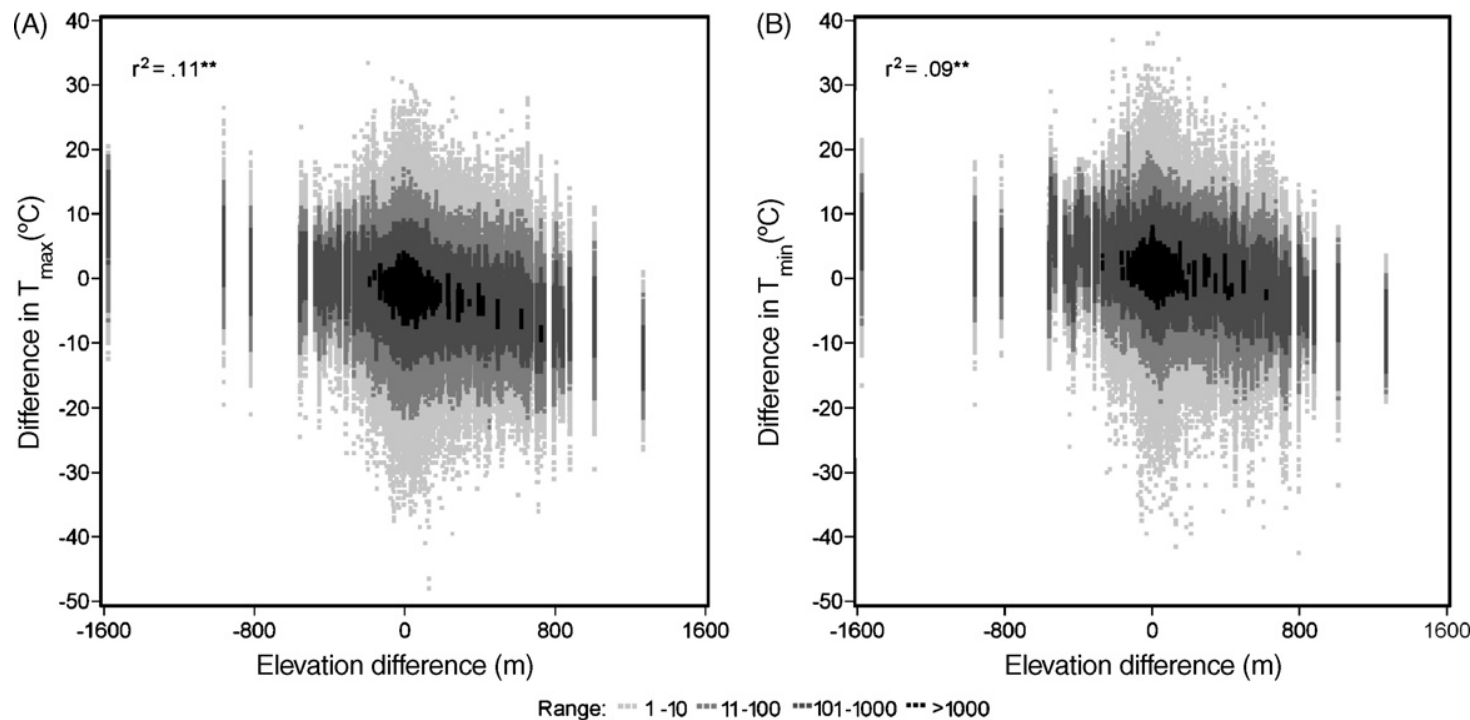

Fig. 3 - Relation between differences in daily temperatures for NASA/POWER grid and NOAA COOP and corresponding elevations of grid cells and their paired COOP station locations: (A) daily maximum temperature; (B) daily minimum temperature. The range indicates the number of data pairs.

Table 4 - Analyses of variance for bivariate or multiple regressions comparing NOAA COOP and NASA/POWER daily temperatures for 855 locations on a $1^{\circ}$ latitude and longitude grid covering the continental US and representing 1983-2004

\begin{tabular}{|c|c|c|c|c|c|c|c|}
\hline COOP temperature variable & Source & $\mathrm{DF}$ & Sums of squares & $\%$ SS & $\beta_{\mathrm{NP}}$ & $r^{2}$ & RMSE \\
\hline \multirow[t]{9}{*}{ Maximum } & NASA/POWER & 1 & $823,806,729$ & 87.8 & 0.94 & 0.88 & 4.1 \\
\hline & Residual & $6,777,982$ & $114,937,193$ & 12.2 & & & \\
\hline & Sine & 1 & $46,941,879$ & 5.0 & & 0.89 & 3.9 \\
\hline & Cosine & 1 & $494,953,752$ & 52.7 & & & \\
\hline & NASA/POWER & 1 & $284,319,796$ & 30.3 & 0.89 & & \\
\hline & Sine $x$ NP & 1 & 60,425 & 0.0 & & & \\
\hline & Cosine $x$ NP & 1 & 179,558 & 0.0 & & & \\
\hline & Elevation dif. & 1 & $12,166,743$ & 1.3 & & & \\
\hline & Residual & $6,777,977$ & $100,121,769$ & 10.7 & & & \\
\hline \multirow[t]{9}{*}{ Minimum } & NASA/POWER & 1 & $683,783,440$ & 87.9 & 0.92 & 0.88 & 3.7 \\
\hline & Residual & $6,777,982$ & $93,937,244$ & 12.1 & & & \\
\hline & Sine & 1 & $40,846,433$ & 5.3 & & 0.89 & 3.5 \\
\hline & Cosine & 1 & $379,079,130$ & 48.7 & & & \\
\hline & NASA/POWER & 1 & $266,792,473$ & 34.3 & 0.90 & & \\
\hline & Sine $x$ NP & 1 & 92,736 & 0.0 & & & \\
\hline & Cosine $x$ NP & 1 & 570,650 & 0.1 & & & \\
\hline & Elevation dif. & 1 & $7,762,988$ & 1.0 & & & \\
\hline & Residual & $6,777,977$ & $82,576,273$ & 10.6 & & & \\
\hline \multirow[t]{9}{*}{ Average } & NASA/POWER & 1 & $738,944,130$ & 91.4 & 0.94 & 0.91 & 3.2 \\
\hline & Residual & $6,777,982$ & $69,528,347$ & 8.6 & & & \\
\hline & Sine & 1 & $43,792,870$ & 5.4 & & 0.93 & 2.9 \\
\hline & Cosine & 1 & $434,559,129$ & 53.8 & & & \\
\hline & NASA/POWER & 1 & $261,889,164$ & 32.4 & 0.89 & & \\
\hline & Sine $x$ NP & 1 & 48,142 & 0.0 & & & \\
\hline & Cosine $x$ NP & 1 & 52,746 & 0.0 & & & \\
\hline & Elevation dif. & 1 & $9,978,591$ & 1.2 & & & \\
\hline & Residual & $6,777,977$ & $57,427,031$ & 7.1 & & & \\
\hline
\end{tabular}

Sums of squares are for sequential entry of variables. Regression coefficients for effect on NASA/POWER data are represented as $\beta_{\mathrm{NP}}$. Sine and cosine effects are calculated for a period 365.25 days. All F-ratios were significant at $P<0.001$ levels so are not shown.

(Fig. 3B and Table 4). Coastal areas also appeared problematic (Fig. 1). Since the NASA/POWER temperature values are averaged over $1^{\circ}$ cells, they would not capture localized sealand temperature gradients (Rotunno et al., 1992).
Simple bivariate comparisons provide an arguably inflated impression of the comparability of weather data sets where there is a strong annual signal. In the regression analysis that included sine and cosine functions, annual variation 
explained about $58 \%$ of the variation in $\mathrm{T}_{\max }, 54 \%$ of $\mathrm{T}_{\min }$ and $59 \%$ of $\mathrm{T}_{\text {avg }}$ from COOP stations (Table 4 ), while the NASA/ POWER temperature data still explained over $30 \%$ of variation in $\mathrm{T}_{\max }, 34 \%$ of $\mathrm{T}_{\min }$ and $32 \%$ of $\mathrm{T}_{\text {avg. }}$.

To determine whether the difference between the NASA/ POWER and COOP data varied with season, the daily mean difference over all cells and stations was calculated and plotted for $\mathrm{T}_{\max }$ and $\mathrm{T}_{\min }$ (Fig. 4). The difference in $\mathrm{T}_{\max }$ varied by over $1.5^{\circ} \mathrm{C}$, with the largest bias occurring between February and March (Fig. 4A). The difference in $\mathrm{T}_{\min }$ was about $1.0^{\circ} \mathrm{C}$ from May to August, but widened to $2{ }^{\circ} \mathrm{C}$ in September and October (Fig. 4B). For both $T_{\max }$ and $T_{\min }$, variability was greater from November to March.

To test how much the temperature observations reflected the short-term variability, such as might result from changes in time of observation of $T_{\max }$ relative to $T_{\min }$ or other local factors, the bivariate regressions were repeated using means over different periods of up to 30 days. The overall goodness of fit of the regressions improved with periods lasting 8 days or longer, as evidenced by the increase in $r^{2}$ and the decline in RMSE (Table 5). Thus, the NASA/POWER data reproduced the variability in temperature better on a weekly or bi-weekly time scale than on a daily scale, presumably due to a reduction in the influence of local, day-to-day fluctuations in temperature.
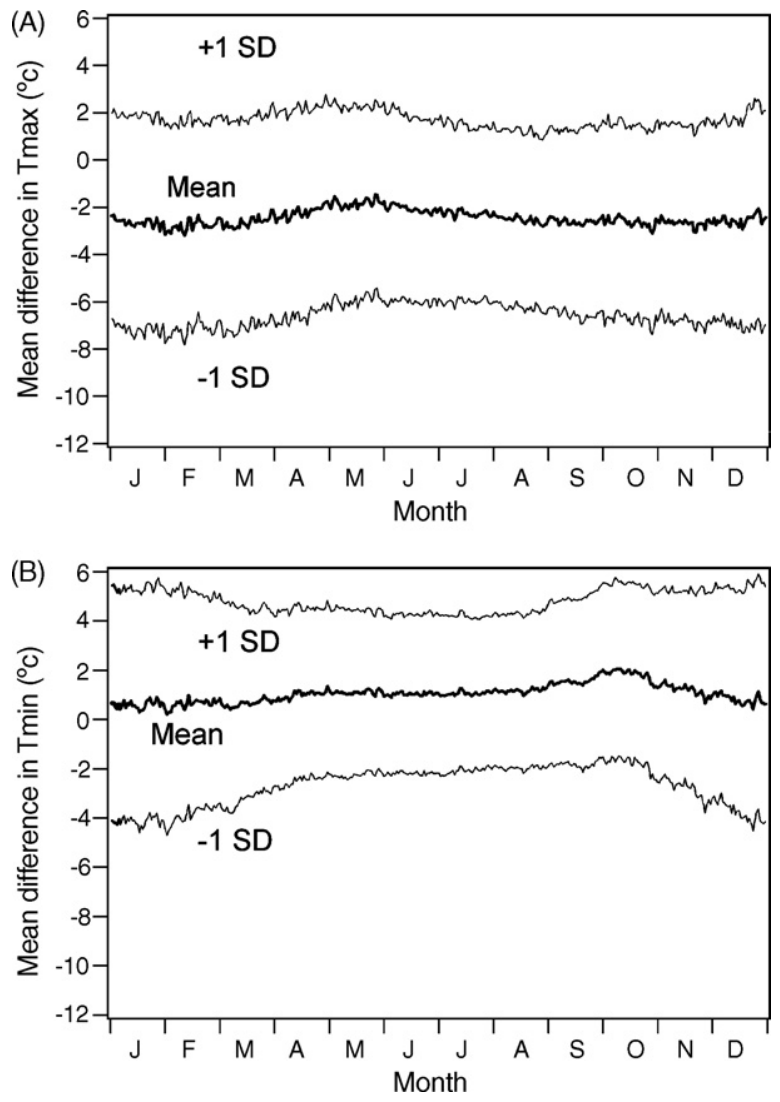

Fig. 4 - Variation in the difference between temperature data from the NASA/POWER grid and 857 NOAA COOP weather stations in relation to time of year. Graphs show daily mean \pm standard deviation: (A) maximum temperature; (B) minimum temperature.
Table 5 - Summary statistics for bivariate regressions comparing NASA/POWER and NOAA COOP temperature data expressed as means over different periods

\begin{tabular}{lcccc} 
NASA COOP variable & Period $(\mathrm{d})$ & $r^{2}$ & $\mathrm{RMSE}\left({ }^{\circ} \mathrm{C}\right)$ & $\beta_{\mathrm{NP}}$ \\
\hline Maximum temperature & 1 & 0.88 & 4.1 & 0.94 \\
& 2 & 0.91 & 3.5 & 0.96 \\
& 4 & 0.93 & 3.0 & 0.96 \\
& 6 & 0.93 & 3.0 & 0.96 \\
& 8 & 0.94 & 2.7 & 0.97 \\
& 10 & 0.95 & 2.7 & 0.97 \\
& 12 & 0.95 & 2.5 & 0.97 \\
& 14 & 0.95 & 2.5 & 0.97 \\
Minimum temperature & 18 & 0.95 & 2.5 & 0.97 \\
& 30 & 0.95 & 2.4 & 0.97 \\
& 1 & 0.88 & 3.7 & 0.92 \\
& 2 & 0.90 & 3.3 & 0.93 \\
& 4 & 0.92 & 3.0 & 0.92 \\
& 6 & 0.93 & 3.0 & 0.94 \\
& 8 & 0.93 & 2.7 & 0.94 \\
& 10 & 0.93 & 2.7 & 0.94 \\
& 12 & 0.93 & 2.6 & 0.94 \\
& 14 & 0.93 & 2.6 & 0.94 \\
& 18 & 0.94 & 2.5 & 0.94 \\
& 30 & 0.94 & 2.5 & 0.94
\end{tabular}

Slopes of the regressions are $\beta_{\mathrm{NP}}$. All $r^{2}$-values are significant at the $p<0.001$ level.

\subsection{Comparisons of simulated days to anthesis using NASA/POWER and COOP data}

Simulations of days to anthesis using the two data sources (Table 6 and Fig. 5) confirmed that the overall agreement between the temperature data sources would result in similar variation in phenology (Fig. 6A and Tables 6 and 7). However, differences of over 100 days occurred, and these appeared partially related to elevation differences (Fig. 6B). An effect of growth habit (winter vs. spring wheat) was also detected, so separate regressions were used to compare means, $r^{2}$-values and RMSE for the two habits. The mean anthesis dates of winter wheat differed by 3 days while spring wheat dates differed by 10 days (Table 6). The $r^{2}$ and RMSE for winter wheat was $0.91(P<0.01)$ and 11.3 days, respectively vs. $0.51(P<0.01)$ and 26.7 days for the spring wheat (Table 7). Presumably, the poor performance for spring wheat is related to the greater differences between the two sets of temperature data from November to March indicated by Fig. 4, which corresponds to a large portion of the period when fall to winter-sown spring wheats are growing but winter wheats are dormant. Including an effect of elevation reduced the RMSE from 11.4 to 8.3 days for winter wheat, as compared to a reduction from 26.9 to 24.6 days for spring wheat. Besides the expected large discrepancies in simulations corresponding to cells containing Mt. Hood and Mt. Washington, large differences occurred in cells along coastlines where the NASA/POWER data may represent large extents of ocean (Fig. 5).

Given the difficulties presented by topographic variation and coastal areas, additional analyses were run focusing on the relatively flat, inland region from $34^{\circ} \mathrm{N}$ to $47^{\circ} \mathrm{N}$ and from $82^{\circ} \mathrm{W}$ to $104^{\circ} \mathrm{W}$. This region covers southern Arkansas to southern North Dakota and eastern Kentucky to western 
Table 6 - Mean, minimum and maximum values of simulated days to anthesis based on NASA/POWER and COOP daily temperature data for 855 locations on a $1^{\circ}$ latitude and longitude grid covering the continental US and representing a time series from 1983 through 2004

\begin{tabular}{|c|c|c|c|c|}
\hline Variable & Temperature data source & Mean & Minimum & Maximum \\
\hline \multirow[t]{3}{*}{ All locations } & NASA/POWER & 224 & 63 & 320 \\
\hline & COOP & 222 & 69 & 361 \\
\hline & Difference between NASA/POWER and COOP & 1 & -107 & 78 \\
\hline \multirow[t]{3}{*}{ Central US } & NASA/POWER & 240 & 174 & 319 \\
\hline & COOP & 239 & 170 & 323 \\
\hline & Difference between NASA/POWER and COOP & 1 & -2 & 23 \\
\hline \multirow[t]{3}{*}{ Winter wheat area } & NASA/POWER & 238 & 75 & 320 \\
\hline & COOP & 234 & 140 & 361 \\
\hline & Difference between NASA/POWER and COOP & 3 & -107 & 78 \\
\hline \multirow[t]{3}{*}{ Spring wheat area } & NASA/POWER & 129 & 63 & 235 \\
\hline & COOP & 138 & 69 & 250 \\
\hline & Difference between NASA/POWER and COOP & -10 & -79 & 70 \\
\hline
\end{tabular}

Nebraska and was assumed to exclusively contain winter wheat. As compared to all winter wheat locations, the mean difference for days to anthesis was 1 day. The RMSE decreased from 11.3 to 5.8 days, while the $r^{2}$-value increased from 0.91 to 0.96 (Table 7). A 6 days RMSE error is comparable to the RMSE of 7-9 days reported in a recent model evaluation based on a large set of winter wheat yield nurseries (White et al., 2008). An effect of elevation difference was still detected $(P<0.001)$, and its inclusion reduced the RMSE to 5.5 days (Table 7).

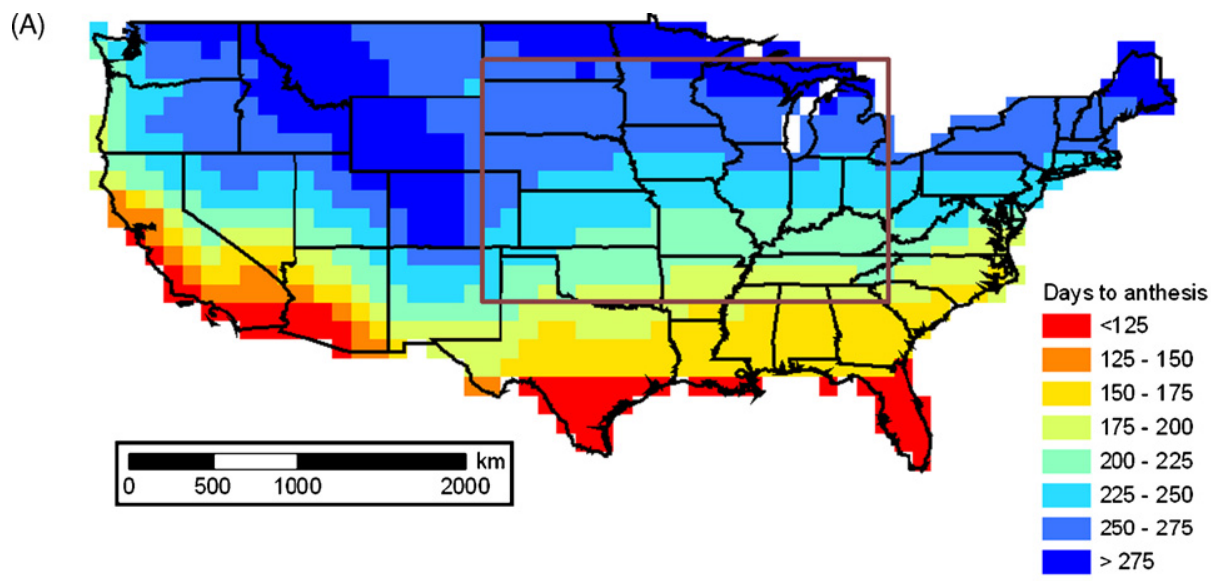

(B)

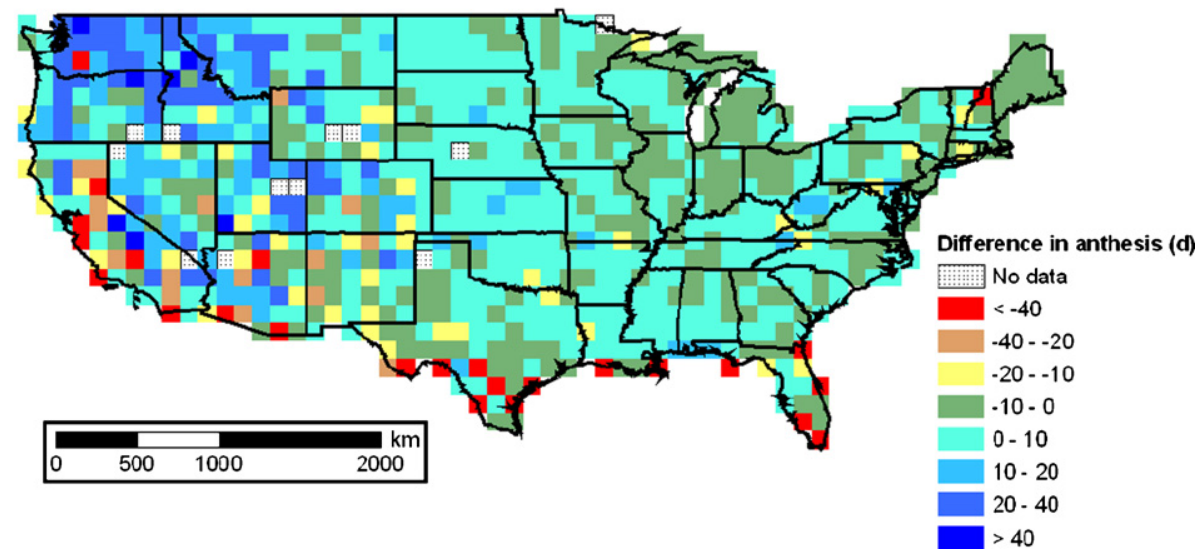

Fig. 5 - Maps of the continental Unites States showing simulations of days to anthesis for 1983-2004. (A) Mean days to anthesis using NASA/POWER temperature data. The rectangle delimits the region from $34^{\circ} \mathrm{N}$ to $47^{\circ} \mathrm{N}$ and from $82^{\circ} \mathrm{W}$ to $104^{\circ}$ W. (B) Difference in days to anthesis for NASA/POWER vs. COOP data. 

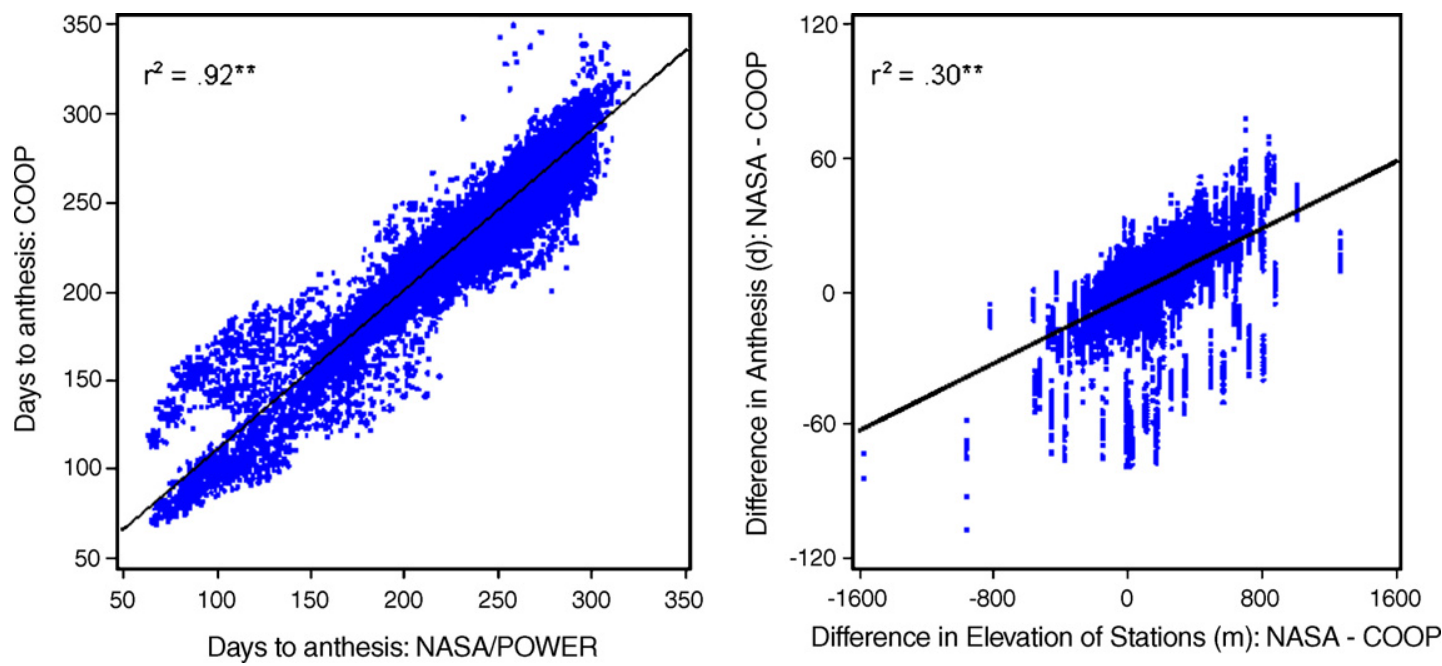

Fig. 6 - Comparisons of simulated days to anthesis using the NASA/POWER grid and NOAA COOP weather stations data: (A) days to anthesis simulated with NASA/POWER data; (B) difference in days to anthesis for NASA/POWER grid and NOAA COOP data vs. difference in elevation of grid cells and their paired COOP station locations.

\section{Discussion}

Overall, the comparisons of both temperature data and simulated anthesis dates support the utility of the NASA/ POWER temperature data for regions showing good agreement. However, users should consider the required geographic scale of analysis. Given the inherent local variability of weather data, the NASA/POWER datasets appear best suited for regional comparisons where the minimum distance of interest is on the order of $100 \mathrm{~km}$ and coastal regions are not involved.

The effect of elevation differences between a NASA/POWER $1^{\circ}$ data cell and a potential region of interest might be mitigated through lapse rates adjustments that consider seasonal and latitudinal variation in the rate as well as differences between rates for $\mathrm{T}_{\max }$ and $\mathrm{T}_{\min }$ (e.g., Neumann, 1955; Hutchinson, 1991). Harlow et al. (2004) estimated

Table 7 - Analyses of variance for regressions comparing simulated days to anthesis using NOAA COOP and NASA/

POWER daily temperatures for 1983-2004

\begin{tabular}{|c|c|c|c|c|c|c|c|}
\hline Habits or region & Source & $\mathrm{DF}$ & Sums of squares & $\%$ SS & $\beta_{\mathrm{NP}}$ & $r^{2}$ & RMSE \\
\hline \multirow[t]{4}{*}{ Spring and winter } & Growth habit & 1 & $17,215,783$ & 40.2 & & 0.92 & 14.2 \\
\hline & NASA/POWER & 1 & $22,035,385$ & 51.4 & 0.93 & & \\
\hline & Habit*N/P & 1 & 122,692 & 0.3 & & & \\
\hline & Residual & 17080 & $3,456,199$ & 8.1 & & & \\
\hline \multirow[t]{2}{*}{ Spring } & NASA/POWER & 1 & $1,616,720$ & 51.3 & 0.72 & 0.51 & 26.7 \\
\hline & Residual & 2161 & $1,537,839$ & 48.7 & & & \\
\hline \multirow[t]{3}{*}{ Spring } & NASA/POWER & 1 & $1,616,720$ & 51.3 & 0.80 & 0.59 & 24.5 \\
\hline & Difference in elevation & 1 & 239,484 & 7.6 & & & \\
\hline & Residual & 2160 & $1,298,355$ & 41.1 & & & \\
\hline \multirow[t]{2}{*}{ Winter } & NASA/POWER & 1 & $20,541,357$ & 91.5 & 0.93 & 0.91 & 11.3 \\
\hline & Residual & 14919 & $1,918,360$ & 8.5 & & & \\
\hline \multirow[t]{3}{*}{ Winter } & NASA/POWER & 1 & $20,541,357$ & 91.5 & 0.98 & 0.95 & 8.3 \\
\hline & Difference in elevation & 1 & 899,265 & 4.0 & & & \\
\hline & Residual & 14918 & $1,019,095$ & 4.5 & & & \\
\hline \multirow[t]{2}{*}{ Mid-western ${ }^{a}$} & NASA/POWER & 1 & $4,792,191$ & 96.3 & 1.01 & 0.96 & 5.8 \\
\hline & Residual & 5511 & 184,817 & 3.7 & & & \\
\hline \multirow[t]{3}{*}{ Mid-western } & NASA/POWER & 1 & $4,792,191$ & 96.3 & 1.01 & 0.97 & 5.5 \\
\hline & Difference in elevation & 1 & 17,900 & 0.4 & & & \\
\hline & Residual & 5510 & 166,917 & 3.4 & & & \\
\hline
\end{tabular}

Comparisons of spring vs. winter habit were for the 855 locations in the continental US, while the mid-western rectangle contained only winter wheat. Regression coefficients for effect on NASA/POWER data are represented as $\beta_{\mathrm{NP}}$. Sums of squares are for sequential entry of source variables. F-ratios were all significant at the $P<0.001$ level so are not shown.

a Covering the region from $34^{\circ} \mathrm{N}$ to $47^{\circ} \mathrm{N}$ and from $82^{\circ} \mathrm{W}$ to $104^{\circ} \mathrm{W}$, which corresponds to southern Arkansas to southern North Dakota and eastern Kentucky to western Nebraska (Fig. 5A). 
separate lapse rates for $T_{\max }$ and $T_{\min }$ for southeastern Arizona, obtaining mean annual values of $6.8^{\circ} \mathrm{C} \mathrm{km}^{-1}$ for $\mathrm{T}_{\max }$ and $3.6^{\circ} \mathrm{C} \mathrm{km}^{-1}$ for $\mathrm{T}_{\text {min }}$. The mean difference in elevation was only $90 \mathrm{~m}$ for our stations, however, so elevation differences are insufficient to explain the mean differences in temperatures (Table 3). Given the seasonal variation in mean differences between the data sources (Fig. 4), more complex adjustments that consider seasonal and regional variation in lapse rate might be needed. The greater error in November to March temperatures, however, may be an unavoidable consequence of the greater variability of winter vs. summer temperatures (e.g., Court, 1951). This variability is likely due in part to the passage of frontal systems during the winter causing larger daily changes in temperature and humidity. For the NASA/POWER data, night-time cooling computations in the winter season are also complicated by localized effects due to topography and changes in ground cover (i.e., vegetation, snow), possibly resulting in larger assimilation model errors.

While elevation differences affected comparability of the two sets of weather data, the overall differences (Table 3) and wide bands of deviations where the elevation difference was less than $200 \mathrm{~m}$ (Fig. 3B) evidenced additional sources of error. An urban heat island effect can bias observed temperatures upward (Arnfield, 2003), which is consistent with our observation that COOP values of $T_{\max }$ were greater than the NASA/POWER values. Mahmood et al. (2006) noted that even in rural areas, station data can be biased when they are located near buildings or asphalt surfaces. Proximity to bodies of water could also bias temperatures. For NASA/POWER data, a cell that largely included ocean or large lakes might show lower values of $T_{\max }$ but higher values of $T_{\min }$. There is some suggestion of such an effect by grid box values shown overlapping open water along coastal areas for the temperature data in Fig. 1.

Since NASA/POWER data correspond to midnight observations time while COOP stations vary in their observation times, TOB also is a possible source of bias. Approximately $70 \%$ of COOP stations report using an AM time and 20\% a PM time, with western regions showing a lower frequency of AM times (Belcher and DeGaetano, 2005). The study of Karl et al. (1986), which considered 79 stations across the US, indicated that a 0700 Local Standard Time (LST) observation can bias values of $\mathrm{T}_{\max } 1^{\circ} \mathrm{C}$ lower than a $2400 \mathrm{LST}$ observation and $2{ }^{\circ} \mathrm{C}$ lower for $\mathrm{T}_{\min }$, but the mean bias for an $0700 \mathrm{LST}$ ranged from 0 to $-0.5^{\circ} \mathrm{C}$ for both $\mathrm{T}_{\max }$ and $\mathrm{T}_{\min }$. The mean bias for $1700 \mathrm{LST}$ observations varied from 0.5 to $1.0^{\circ} \mathrm{C}$ for $T_{\max }$ and 0.2 to $0.7^{\circ} \mathrm{C}$ for $\mathrm{T}_{\text {min }}$. Large regional and seasonal differences were noted (Karl et al., 1986). However, further study would be needed to determine whether the overall difference between NASA/ POWER and COOP temperatures is largely due to TOB. The improved RMSE values obtained when data were averaged over 8-day or longer periods (Table 5) might reflect the compensation for time of observation.

An underlying problem with our analysis is the lack of a means to assess the error of the COOP temperature data. Analyses by other groups on limited sets of COOP stations indicate that station to station error can be as high as $2-4{ }^{\circ} \mathrm{C}$, with the largest errors being attributable to inappropriate instrument exposure and TOB (Wu et al., 2005; Holder et al., 2006; Mahmood et al., 2006).
While NOAA COOP data are indisputably a key resource for research that involves the climate of the US, their usefulness is diminished by missing data, discontinuation of observations at some locations, and the long delay between when observations are made and when data are made available. For regional scale applications, the NASA/POWER temperature data offer researchers the advantage of providing a continuous record from 1983 onward, with data being accessible in less than 1 month, and the possibility exists that temperature and other parameters such as solar data could be made available with only a few days delay.

\section{Conclusions}

Considering the constraints inherent with its coarse grid cell size of $1^{\circ}$ of latitude and longitude, the NASA/POWER daily temperature data showed good agreement with data from COOP stations. Simulations of flowering time were most comparable for winter wheat regions in the central US. The deviations between the two temperature data sources were attributable in part to cells representing regions with large variation in elevation, suggesting that adjustments the NASA/ POWER data might be scaled to local conditions using lapse rate adjustments. The adjustments should differ for $\mathrm{T}_{\max }$ and $\mathrm{T}_{\min }$ and vary with season and geographic region. Further improvements in accuracy might require more complex adjustments for landscape position, especially influences of large bodies of water or a revision of the GEOS assimilation model to reduce the seasonal variation in bias. Given that NASA/POWER data are available for over 23 years with global coverage and are continuously being updated, they represent a potentially valuable source of daily temperature data for research and management applications concerned with regional to global geographic scales.

\section{Acknowledgements}

We acknowledge the valuable assistance of Belinda Wernau in processing of the NOAA data. Portions of this work were funded by a grant from the NASA's Applied Science Rapid Prototype program through the NASA Langley Research Center under Contract NN07AA00C with Science Systems and Applications, Inc. and a Special Research Grant from the US Department of Agriculture, Cooperative State Research, Education, and Extension Service (CSREES).

\section{R E F E R E N C E S}

Arnfield, A.J., 2003. Two decades of urban climate research: a review of turbulence, exchanges of energy and water, and the urban heat island. Int. J. Climatol. 23, 1-26.

Belcher, B., DeGaetano, A.T., 2005. A method to infer time of observation at US Cooperative Observer Network stations using model analyses. Int. J. Climatol. 25, 1237-1251.

Bloom, S., A. da Silva, D. Dee, M. Bosilovich, J.-D. Chern, S. Pawson, S. Schubert, M. Sienkiewicz, I. Stajner, W.-W. Tan, M.-L. Wu, 2005. Documentation and Validation of the 
Goddard Earth Observing System (GEOS) Data Assimilation System, Version 4. Technical Report Series on Global Modeling and Data Assimilation. NASA/TM-2005-104606, vol. 26.

Court, A., 1951. Temperature frequencies in the United States. J. Meteorol. 8, 367-380.

Daly, C., 2006. Guidelines for assessing the suitability of spatial climate datasets. Int. J. Climatol. 26, 707-721.

Davey, C.A., Pielke Sr., R.A., 2005. Microclimate exposures of surface-based weather stations. Bull. Am. Meteorol. Soc. 86, 497-504.

Harlow, R.C., Burke, E.J., Scott, R.L., Shuttleworth, W.J., Brown, C.M., Petti, J.R., 2004. Research Note: Derivation of temperature lapse rates in semi-arid south-eastern Arizona. Hydrol. Earth Syst. Sci. 8, 1179-1185.

Holder, C., Boyles, R., Syed, A., Niyogi, D., Raman, S., 2006. Comparison of collocated automated (NCECONet) and manual (COOP) climate observations in North Carolina. J. Atmos. Ocean. Technol. 23, 671-682.

Hoogenboom, G., Jones, J.W., Wilkens, P.W., Porter, C.H., Batchelor, W.D., Hunt, L.A., Boote, K.J., Singh, U., Uryasev, O., Bowen, W.T., Gijsman, A., du Toit, A., White, J.W., Tsuji, G.Y. 2004. Decision Support System for Agrotechnology Transfer, Version 4.0. Honolulu, HI: University of Hawaii (CD-ROM software).

Hubbard, K.G., Lin, X., Walter-Shea, E.A., 2001. The effectiveness of the ASOS, MMTS, Gill, and CRS air temperature radiation shields. J. Atmos. Ocean. Technol. 18, 851-864.

Hunt, L.A., Pararajasingham, S., 1995. Cropsim-wheat: a model describing the growth and development of wheat. Can. J. Plant Sci. 75, 619-632.

Hunt, L.A., White, J.W., Hoogenboom, G., 2001. Agronomic data: advances in documentation and protocols for exchange and use. Agric. Syst. 70, 477-492.

Hunt, L.A., Hoogenboom G.H., Jones, J.W., White, J.W., 2006. ICASA, Version 1.0, Data Standards for Agricultural Research and Decision Support. http://www.icasa.net/ standards/index.html (verified March 25, 2008.).

Hutchinson, M.F., 1991. The application of thin plate smoothing splines to continent-wide data assimilation. In: J.D. Jasper (Ed.) Data Assimilation Systems. BMRC Research Report No. 27: Bureau of Meteorology, Melbourne, pp. 104-113

Jones, J.W., Hoogenboom, G., Porter, C.H., Boote, K.J., Batchelor, W.D., Hunt, L.A., Wilkens, P.W., Singh, U., Gijsman, A.J., Ritchie, J.T., 2003. The DSSAT cropping system model. Eur. J. Agron. 18, 235-265.

Karl, T.R., Williams C.N.Jr., Young, P.J., Wendland, W.M., 1986. A model to estimate the time of observation bias associated with monthly mean maximum, minimum and mean temperatures for the United States. J. Climate Appl. Meteorol. 25, 145-160.

Mahmood, R., Foster, S.A., Logan, D., 2006. The GeoProfile metadata, exposure of instruments, and measurement bias in climatic record revisited. Int. J. Climatol. 26, 1091-1124.

Neumann, J., 1955. Latitudinal variation of tropospheric temperature lapse rate. Arch. Meteorol. Geophys. Bioclimatol. A 8, 351-353.

NOAA. 2006. National Weather Service's Cooperative Observer Program. http://www.nws.noaa.gov/om/coop/ (verified March 25, 2008).

Pielke Sr., R.A., Davey, C., Niyogi, D., Fall, S., Steinweg-Woods, J., Hubbard, K., Lin, X., Cai, M., Lim, Y.-K., Li, H., NielsenGammon, J., Gallo, K., Hale, R., Mahmood, R., Foster, S., McNider, R.T., Blanken, P., 2007. Unresolved issues with the assessment of multi-decadal global land surface temperature trends. J. Geophys. Res. 112, D24S08.

Ritchie, J.T., 1991. Wheat phasic development. Modeling Plant and Soil Systems. ASA-CSSA-SSSA, Madison, WI, pp. 31-54.

Ritchie, J.T., Singh, U., Godwin, D.C., Bowen, W.T., 1998. Cereal growth, development and yield. In: Tsuji, G.Y., Hoogenboom, G., Thornton, P.K. (Eds.), Understanding options for agricultural production. Kluwer Academic Publishers, Dordrecht, The Netherlands, pp. 79-97.

Rotunno, R., Curry, J.A., Fairall, C.W., Friehe, C.A., Lyons, W.A., Overland, J.E., Pielke, R.A., Rogers, D.P., Stage, S.A., Geernaert, G.L., Nielsen, J.W., Sprigg, W.A., 1992. Coastal Meteorology-A Review of the State of the Science. Panel on Coastal Meteorology, Committee on Meteorological Analysis, Prediction, and Research, Board on Atmospheric Sciences and Climate, Commission on Geosciences, Environment, and Resources, National Research Council, National Academy Press, Washington, DC, 99 pp.

SAS Institute, Inc., 2000. SAS/STAT User's Guide, Cary, NC, USA.

Stackhouse, P., 2006. Prediction Of Worldwide Energy Resources. http://power.larc.nasa.gov (verified March 24, 2008).

White, J.W., Boote, K.J., Hoogenboom, G., Jones, P.G., 2007. Regression-based evaluation of ecophysiological models. Agron. J. 99, 419-427.

White, J.W., Herndl, M., Hunt, L.A., Payne, T.S., Hoogenboom, G., 2008. Simulation-based analysis of effects of Vrn and Ppd loci on flowering in wheat. Crop Sci. 48, 678-687.

Wu, H., Hubbard, K.G., You, J., 2005. Some concerns when using data from the Cooperative Weather Station Networks: a Nebraska case study. J. Atmos. Ocean. Technol. 22, 592-602. 